\title{
Tales and allegories of vision Ghazali and Rumi
}

\author{
Seyed Mohammad Bagher Kamaladdini \\ Department of Persian Literature and Language, Yazd Branch, Payam-e-Noor University, Yazd, Iran \\ E-mail address: kamaladdini@pnu.ac.ir
}

\begin{abstract}
Among many tribes and nations fiction has a long history as a popular entertainment. The importance of stories is no secret. The meanings of the stories are quite concrete and contacts, events, and eventually finds it earlier. The Persian speakers from early to latet, moral themes, mysticism, religion and other things have taken advantage of this genre. The analogy is meant to provide an example of the eloquence and understanding has long had an important role and are responsible. It is also seen in ancient books and scriptures. Instead, it's like taking the analogy a little word to the land. In this allegory, Masnavi stories and ehya'al oloom are analyzed.
\end{abstract}

Keywords: Tales; Allegory; Masnavi; ehya'al oloom; Rumi; Ghazali

\section{INTRODUCTION}

Rumi's Masnavi is trying to tell his story, like the teacher who is sympathetic to the welfare of human beings leads. The stories Ghazali disagreed with Guyana, agreed with the Koran story. Stories like that of the Quran is the religious and moral education. Hence all the verses invites reflection and contemplation. Allegory, Masnavi The syntax used is very beautiful and ehya'al oloom. So that both Rumi and Al-Ghazali, an effective metaphor as a literary style.

\section{GHAZALI AND HIS EHYA AL OLOOM}

Muhammad Aboo Hämed Hojjatoleslam Ghzalytvsy, in the year 450 AD. Ah, Tabran Tus was born in the village. His father, who was a pious and Svfymslk profession or Pshmfrvshy Ghazali said. Muhammad spent his childhood and youth in Danshandvzy and tourism in the border until the age of forty scholars excelled in various disciplines of science of his time, and his name became famous all over the world. He arrived in Baghdad in 484 and Nzamyh city of Tus, taught and became famous, So that all of his many talents and rich students spoke. 487 year as a professor Selected Nzamyh Baghdad funeral Almstzhrballh installed on the seat of the Caliphate, he participated with his homage. After having reached the peak of fame and glory, Mrdmgryz and leave all at once and ended up lifetime spent in obscurity and cloister. In this case, in a letter written in the year 504, the controversial life of aristocratic regretted his past, he writes: 
"In Baghdad, the debate is not the choice I would not refuse the capital." (Iqbal, 1354: 45)

His deep and important writings, and breathed new life into the form of Islamic sciences in the field of mysticism, philosophy, theology, psychology, ethics, innovation, and finally in the year 505 after fifty-five years of fruitful life, lamp life in native to fade.

Ahya'allvm famous works of Imam Ghazali in Arabic, which is the subject of religious and ethical issues and the summary of Ghazali's Persian language called "alchemy of happiness" by which scholars have considered it a mystical Islamic Encyclopedia. Ehya'al oloom, comprehensive and unique book is the largest and most important center in Baghdad Nzamyh knowledge in the Islamic world has been taught that day and most of his books, has had an impact in a word, the if you want to introduce resuscitation must say that in spite of this it is said that:

"If the Islamic sciences is destroyed, all of the books can be pulled revival."

\section{MASNAV I OF RUMI AND HIS}

Jalaluddin Rumi, known as Rumi, the great mystic poets of Iran in the seventh century and is the son of Baha Valad, who was born in Balkh, But Bhvasth Tvlanysh stay in Konya, Rumi, or Rumi was a famous Roman. Maulana Mohammad Khwarazmshah was close to his father's court, where he became resentful However, due to the 610 years of the pilgrimage went and met Sheikh Attar of Nishapur Jalal al-Din Attar's book to a young child and Asrarnamh was awarded.

Baha After the pilgrimage, he went to Larndh will stay there for 7 years. Then went to Konya, where he guided the creation of lifetime payments. Rumi's father died after the events of Trbytyaftgan Bha'vld Mhqqtrmzy Burhanuddin course, the acquisition of grace and truth was introduced to the secrets of wisdom and guidance, and to permit him to pay for the education of students with great mystic Shamseddin Mohammad Tabrizi hit. After the meeting, Maulana Shams Shyfth was such that he left the pulpit and was kid. Hsamaldyn while Chalabi devotion to compose sonnets and Masnavi intimately and worked until he died in the year 672 . Rumi's spiritual and literary influence, not only in Iran, India and Central Asia, but has spread Mghrbzmyn and his works have been translated into various languages. Masnavi is the greatest works of mystical poetry, the ocean, "Raml Msds crossed" the whole poem written and include six office to reach 25 thousand bits. Rumi's Masnavi contains anecdotes that purpose machine guns lay down their order of frequency, which is ethical and religious, mystical and lies everywhere around it. As a short story long, the occasion is also another story in the news about the sayings and verses to confirm the story is mentioned.

\section{LIKE THE STORY}

Humans hear and read the stories and legends of ancient times were not relish the very reason that most of the literature of the world, the story emerged. Less society can be found in various stories Social Pahlevani religious, Eshghi, epic ... They may not.

If the stories in order to help man and pushing him towards the welfare and perfection have been self-education are the most effective. Is unusually important part of the Bible, including stories of the Holy Quran in various forms, since the training of the speech and appealing personal story and the story Brtamvz others are done efficiently so that they directly 
address human or give advice about him, praise and blame, Rvadarnd. As Saadi confirmed this, saying:

If the seeds over the chicken hen sees other animals not involved (Saadi, 1329: 194)

More stories in the Masnavi, Rumi's books ahead of time, history, traditions, and news (both poetry and prose), there is seized to the extent that they are pillars of Rumi's mystical purposes, educational, moral, religious and tailored to their academic, Byrvnq the original source of the story as the subject and the content is limited to the fullest extend of Rumi are so much higher than a normal Qsh and becomes a collection of various sciences. Sometimes Rumi's story changed from a quiet little stream, and tempestuous ocean creates a very precious gems and secrets that are hidden in their infinite.

Rumi's words, stories, educational purposes, scientific, spiritual and religious plays aimed not only storytelling, But it is a compassionate teacher and mystic and reformer to be aware of the dark side of human life and human clarify his remarks to Dlavyz leads to welfare. Ghazali, however, was opposed to the storytellers, but the story is that it has a moral and religious education, advocacy and believes that everyone should think and meditate on the stories of the Quran to Because a large part of the Qur'an is accounted for and constitutes an example. Rumi's worldview also good Qsh one of the best ways to express the teachings of God and His plans to look more to the story content.

Brother is a story of such treaties For example grain means he is involved. Means to be male seed of wisdom If the module was quoted Nngrd (Mathnawi, II Bureau: 451)

If the story aside, another significant problem in Masnavi Ahya'allvm, widespread use of analogy. So that both Rumi and Al-Ghazali, effectively acting as a literary style, and no doubt both of these ways are influenced by the Quran; Maulana educational aspects of analogy as the story is well aware of this case over Ghazali focuses on:

The rest of the characters in literature For example, the teacher needs (Mathnawi, vol: 100).

\section{STORIES AND PARABLES ARE MATHNAWI IN AHYA'ALLVM ALSO}

\section{1. Floss to keep your mouth rude person who called the Prophet (SAW) used to make fun of:}

Apparently derived from the narrative: and Hky Al-Hakam ibn Alas bin Wael Mshyth peace Msthzya Fqal (p) Fkn Kzlk Yzl Yrtsh even opaque film (Ahya'allvm, vol 2, p 257).

\section{2. Zrayyl looking man:}

The forenoon was Sadhmrdy The former Justice David Solomon. In this tale of Ahya'allvm (C 4, p 337) can see.

\section{3. Coming to the life of the Apostle Roman Emperor:}

G. Kaiser, a messenger came to life in the desert of Madinah Nghvl. Apparently messenger conversation with the people of Medina (the Caliph's palace where a retinue ...) is derived from the story of his journey to Medina Hatem irrational and that Ahya'allvm (vol 1, $\mathrm{p} 50$ ) is observed. 


\section{4. Qsh Sufi and Chinese:}

They told us our Chinese Nqashtr Romans deaf and Far. The source of the story is as follows: The people have He suggests China and the people of the Roman Was a tale of Roman and Chinese

\section{5. Ask the Prophet (Slyallh against) the people's lives ... :}

Zaid told the prophet Traveling Bags Asbht a faithful friend. Source of this article, narrated that al-Ghazali ehya'al oloom (C-4, page 157) has quoted.

\section{6. Spit dropping adversary on Ali (peace):}

Ali. student acts of devotion to don the lion decent Kites. Apparently, the story of the capture of Mvlanast features, is derived from Ghazali says that Ahya'allvm narrative is thus: While anger and irritation ... .

\section{7. Stating that seek to conquer the Prophet (pbuh) was born in Mecca and Miscellaneous property to a friend:}

Who was the prophet leaps to Mecca in the world accused of love. He is the repository of the heavens eye exam day rule. Detailed narrative Ahya'allvm (vol 1, p 171, vol 3, p 237 and C-4, pp. 140, 159) is quoted.

\section{8. Coming to the hospital to ask friends are Zvalnvn:}

Egyptian Zvalnvn Kandrv Ftad such passion and madness of New beryl. Source, it is a story that Ahya'allvm (C 4, p 53) is quoted.

\section{9. Empowers bird jumping the other chicken was gay:}

Hakimi said it saw a single crow in the desert with Lklky. Source versions are: Malik bin Dinar said, does not agree.

\section{10. Revelations to Moses Hqtaly why did not you come to visit me:}

Moses was inspired by the dawn of the new moon seen from the pocket square Tyb. Ahya'allvm the narrative, so that More telling is the anniversary of Rumi: and referring to him by the Almighty to Moses (Alshalsalam) got sick did not promise me he said, O Lord, How do View Abdi said so and so did not prepared and if he has promised to find me (Ahya'allvm, vol 4, p 218).

\section{11. Differences in how the cell:}

Cells involved in supply brought the house was dark Bvdndsh Hnvd. This parable ehya'al oloom Ghazali (C 4, p 6) is given.

\section{12. Patience Luqman (peace) ... :}

Luqman was fun to see that he was the David of the iron rings. It is in anecdotal references Ahya'allvm (C 3, page 83) are listed. 


\section{13. The Eagle snatch Museum Messenger (peace):}

Both thumbs up out of the museum and the museum Brbvd a Rabbi Museum. Source versions are:Kahn's Messenger (SAW) inasmuch Arad Alhajh after walking (Ahya'allvm, vol 2, p 176).

\section{14. Qsh not Eat the chicken, which will regret the past:}

It was one of the bird and animal trick Hen Kai-Khawaja said he Hammam. The source of the story is as follows People shit that my polo Israel (Ahya'allvm, vol 3, p 166).

\section{15. Telling Moses that Pharaoh Take my advice:}

G. Gee, I just take one thing and turn it off I get the following four. Its source is: Favhyallh Lmvsy the twin ... And ehya'al oloom (C 4, p. 75).

\section{16. Revelations to Moses Hqtaly I love you I love:}

Moses said to the revelation of God's heart, you'll love the selection of See ehya'al oloom, vol 4, p 185.

\section{17. Gabriel Khalil said you need?}

He taught literature Rod Jibril ask the right Khalil Murad. Below is the news source ehya'al oloom (volume 2, page 201): And the Prophet saw Gabriel twice in shape and told her that he would cover the horizon.

\section{18. The mission statement of Jews and Christians believe in the dignity of the} Prophet (SAW):

They worshiped a god that humans can detect them sooner. And see also ehya'al oloom (c. 3, p 130).

\section{19. God said to the serpent pushed the big animal like this Hunt:}

The story has its source in Ahya'allvm (C 3, page 26): Abvhmamh said that the Messenger of Allah said....

\section{20. The tale of a lover who loves to serve and fulfill its own counting:}

Serve your sweetheart a love in his work and considers. The following story is the basis of Ahya'allvm (C 4, p 251): Aljnyd smelt burning polo Mtlqa ... .

\section{21. Solicitorship Yrjy I Rahma of Allah Almighty:}

Hadith of the day came in Rstkhyz Is that every one of the rich. The following story is the basis of ehya'al oloom (C 4, p 106).

\section{22. She was the cock from the sky before all his time on his Nrhhay:}

The content of this bit is derived from the following narrative Blghny under Alrsh ... (Ahya'allvm, vol 1, p 244). 


\section{23. The return expression Nsvh:}

The following story is the basis of ehya'al oloom (C 4, p 270): Before Kahn and statesman Ykhrj ... . The following story is the basis of ehya'al oloom (C 4, p 270): A man got out and was told.

\section{24. A tale of greed, he became aware that Sheikh discipleship:}

Sheikh discipleship promptly went to the city where the bread was not. It is anecdotal references ehya'al oloom (C 3, p 61).

\section{25. Tell the story of Amir, a servant to bring wine said:}

There was a king who drink wine and had a good heart Kahf every drunk and had poor Appears to be derived from the following indicators: (ehya'al oloom, vol 2, p 247).

\section{26. The Tale of Heman fighting in the trenches every day dermal cast:}

In his hand was a forty dermis and every night it poured in seawater. And this suggests a difference in the amount of wealth, is the ehya'al oloom (c. 3, p 19).

\section{CONCLUSIONS}

The results of this paper can be obtained, this is a great mystics, have paid special attention to the stories and allegories in his works of this genre, as the best means to learn and teach the masses to have looked at.Also thought to be the same two authors, always adapted to one another because, not some kind of intellectual Tvard. Masnavi of Rumi and ehya'al oloom Ghazali two is something which can be compared in terms of attention to the story and acting are compared.

\section{References}

[1] The Holy Quran; https://www.alislam.org/quran/

[2] Saadi Mosleh al-Din (1951). Golestan, Mohammad Ali Foroughi correct, Tehran: Win.

[3] Ghazali Imam Muhammad (1982 AH). Al Rehabilitation Sciences, 5 (c), Beirut: Daralmrfh.

[4] Ghazali Imam Muhammad (1976). Mkatyb Persian, correction: Abbas Iqbal.

[5] Mawlana Jalal al-Din Muhammad (1987). Masnavi (6 offices), to correct Elin Reynold Nicholson, publisher Lord, Tehran. 